\title{
Productive and Nutritional Aspects of Tithonia diversifolia Fertilized With Biofertilizer and Irrigated
}

\author{
Matheus M. Reis ${ }^{1,2}$, Leonardo D. Tuffi Santos ${ }^{2}$, Rodinei F. Pegoraro ${ }^{2}$, Marcia V. Santos ${ }^{3}$, Fernando Colen², \\ William G. Montes ${ }^{2}$, Ronie R. Moura Jr. ${ }^{2}$, Leandro R. da Cruz ${ }^{4} \&$ Flávio G. Oliveira ${ }^{2}$ \\ ${ }^{1}$ School of Agricultural Engineering, University of Campinas, Campinas, Brazil \\ ${ }^{2}$ Institute of Agrarian Sciences, Federal University of Minas Gerais, Montes Claros, Brazil \\ ${ }^{3}$ School of Agrarian Sciences, Federal University of Vales do Jequitinhonha e Mucuri, Diamantina, Brazil \\ ${ }^{4}$ School of Agriculture, São Paulo State University, Botucatu, Brazil \\ Correspondence: Matheus M. Reis, Institute of Agrarian Sciences, Federal University of Minas Gerais, Montes \\ Claros, Minas Gerais, Brazil. Tel: 55-038-2101-7781. E-mail: matheussmendes@hotmail.com
}

Received: July 24, $2018 \quad$ Accepted: August 26, $2018 \quad$ Online Published: October 15, 2018

doi:10.5539/jas.v10n11p367 URL: https://doi.org/10.5539/jas.v10n11p367

\begin{abstract}
Little is known about the agronomic aspects of Mexican Sunflower (Tithonia diversifolia), in spite of its potential for multiple uses. In this study, we evaluated the effects of application rates of biofertilizer and irrigation on yield, growth, and leaf chlorophyll and nutrient content of Mexican Sunflower. In an experiment in the Brazilian semi-arid region, we used a $5 \times 2$ factorial arrangement, consisting of five application rates of biofertilizer $\left(0,40,80,120\right.$, and $\left.160 \mathrm{~m}^{3} \mathrm{ha}^{-1}\right)$, with and without irrigation. The statistical design was randomized blocks with three replications. Irrigated plants of Mexican Sunflower had greater dry and fresh matter yields, greater height, and greater leaf area index and leaf contents of $\mathrm{K}, \mathrm{Zn}$, and B. However, the high concentration of bicarbonate in the irrigation water reduced the leaf contents of $\mathrm{N}, \mathrm{Ca}, \mathrm{S}, \mathrm{Fe}$, and $\mathrm{Mn}$. The mean increase in the two cuttings obtained with the use of irrigation was $350 \%$ and $314 \%$ for fresh and dry matter, respectively. The increase in the biofertilizer application increased the leaf chlorophyll contents of irrigated plants; however, it did not result in production or nutritional gains. In regions with low availability of rainfall, irrigated cultivation of Mexican Sunflower is recommended.
\end{abstract}

Keywords: biomass, chlorophyll, leaf area index, nutrient availability, organic fertilization, Titonia

\section{Introduction}

Tithonia diversifolia (Hemsl.) A. Gray, also known as Mexican Sunflower, Botón de Oro, Wild Sunflower or Titonia, is a bush of the Asteraceae family, originating from Central America and widely distributed in tropical regions (Ramírez-Rivera et al., 2010).

Studies indicate this plant as a promising food source for ruminants (Osuga, Abdulrazak, Muleke, \& Fujihara, 2012), swine (Fasuyi \& Afolabi, 2013), rabbits (Ajayi, Farinu, Ojebiyi, \& Olayeni, 2007), and birds (Medina \& Carreño, 1999), as well as a green manure crop, soil plant cover, raw material for the pharmaceutical industry, hedge, and windbreak, among other uses (Reis, Cruz, Da Costa, Barros, \& Tuffi Santos, 2015).

In spite of its potential for multiple uses, little is known regarding the agronomic aspects of this plant in Brazil and in the world. Studies on the production of pharmacological compounds (Owoyele, Wuraola, Soladoye, \& Olaleye, 2004), bromatological composition (Osuga et al., 2012), and accumulation of leaf nutrients (Sao, Mui, \& Binh, 2010) are mainly developed in Central American and African countries. Nevertheless, recommendations on fertilization, soil preparation, management, harvest, and response to irrigation have not yet been reported in the scientific literature.

The use of biofertilizers may be an interesting alternative for improvement of soil fertility, along with reuse of organic waste. Organic matter and nutrients supplied from organic waste and from other organic compounds improve soil physical and chemical characteristics, which explains the growing use of organic fertilizers in agriculture (Santos et al., 2013a). 
Another noteworthy factor is the use of water in agriculture, especially in arid and semi-arid regions, where this resource is scarce. Water is one of the main inputs that most frequently limits the efficiency of agricultural production systems (Taiz \& Zeiger, 2013; Ul-Allah, Khan, Fricke, Buerkert, \& Wachendorf, 2015) because its lack or excess significantly reduces crop yield (Xiao, Zhang, Jia, Pang, \& Guo, 2015). Thus, adequate management of irrigation becomes necessary to meet crop water needs, thus obtaining greater economic return (Ul-Allah et al., 2015; Xiao et al., 2015).

In this study, we evaluated the use of bovine biofertilizer on the yield, chlorophyll contents, and nutritional aspects of Mexican Sunflower (T. diversifolia) grown with and without irrigation in a Brazilian semi-arid region.

\section{Method}

\subsection{Study Area and Experimental Desing}

The experiment was conducted over two consecutive growing seasons, from June 21 to November 28, 2015, in Montes Claros, Minas Gerais, Brazil (16²40'57.70" S; 4350'19.62" W; 650 m).

Climate in the region according to the Köppen classification is Aw, hot tropical with a dry winter, and soil of the experimental area is a Cambissolo Háplico eutrófico with a clayey-silty texture (Santos et al., 2013b). At the beginning of the trial, soil samples from the $0-0.2 \mathrm{~m}$ layer exhibited $7.67 \mathrm{pH}$ in water; $36.60 \mathrm{~g} \mathrm{~kg}^{-1}$ organic matter; 1.88 and $137.67 \mathrm{mg} \mathrm{dm}^{-3}$ of $\mathrm{P}$ and $\mathrm{K}$ (Mehlich-1), respectively; 7.07, 1.60, 1.05, and $10.06 \mathrm{cmo}_{\mathrm{c}} \mathrm{dm}^{-3}$ of $\mathrm{Ca}, \mathrm{Mg}, \mathrm{H}+\mathrm{Al}$, and $\mathrm{CEC}$, respectively; and $89.67,19.47,38.80$, and $41.73 \%$ of $\mathrm{V}$, sand, silt, and clay, respectively.

The statistical design of the trial was randomized blocks, with three replications, in a $5 \times 2$ factorial arrangement. Treatments consisted of application rates of bovine biofertilizer $\left(0,40,80,120\right.$, and $\left.160 \mathrm{~m}^{3} \mathrm{ha}^{-1}\right)$, with and without application of irrigation water ( 0 and $100 \%$ of reference evapotranspiration-ETo). These rates of biofertilizer correspond to $0,50,100,150$, and $200 \%$ of the $\mathrm{N}$ recommendation for sunflower (Ribeiro, Guimarães, \& Alvarez, 1999). As there are no specific fertilization recommendations in the scientific literature for Mexican Sunflower, the recommendation of $\mathrm{N}$ fertilization for sunflower was used as a basis, due to the botanical and morphological proximity between the species.

\subsection{Management of Fertilization and Irrigation}

The bovine biofertilizer used in the experiment is derived from a solar biodigester and chemically analyzed according to the method proposed by the Ministério da Agricultura, Pecuária e Abastecimento (2007), exhibiting the characteristics described in Table 1 . Half of the biofertilizer application rates $\left(0,20,40,60\right.$, and $\left.80 \mathrm{~m}^{3} \mathrm{ha}^{-1}\right)$ was applied three days before planting (December 3, 2014) and the other half was topdressed soon after the last cutting for uniformity (June 21, 2015).

Table 1. Chemical characteristics of the bovine biofertilizer (BBF) applied at planting and topdressing, and amounts of nutrients applied with the different application rates of biofertilizer

\begin{tabular}{|c|c|c|c|c|c|c|c|c|c|c|c|c|c|}
\hline \multirow{2}{*}{ Material } & \multicolumn{13}{|c|}{ Chemical characteristics of the bovine biofertilizer } \\
\hline & EC & $\mathrm{pH}$ & OM & $\mathrm{OC}$ & $\mathrm{N}$ & $\mathrm{P}_{2} \mathrm{O}_{5}$ & $\mathrm{~K}_{2} \mathrm{O}$ & $\mathrm{CaO}$ & $\mathrm{Mn}$ & $\mathrm{Fe}$ & $\mathrm{Mg}$ & $\mathrm{S}$ & $\mathrm{Na}$ \\
\hline \multirow[b]{2}{*}{$\mathrm{BBF}$} & $\mathrm{dS} \mathrm{m} \mathrm{m}^{-1}$ & & & & & - & - & $-\mathrm{g} \mathrm{L}^{-1}$ & - & - & - & --------" & - \\
\hline & 5.27 & 7.66 & $\begin{array}{l}16.5 \\
1\end{array}$ & 9.14 & 1.56 & 1.30 & 1.76 & 0.56 & 0.76 & 0.32 & 0.69 & 0.22 & 0.26 \\
\hline \multicolumn{14}{|c|}{ Amounts of nutrients applied $\left(\mathrm{kg} \mathrm{ha}^{-1}\right)$} \\
\hline \multirow[t]{2}{*}{ Rates $\left(\mathrm{m}^{3} \mathrm{ha}^{-1}\right)$} & \multicolumn{13}{|c|}{ Bovine biofertilizer applied at planting and topdressing } \\
\hline & $\mathrm{N}$ & $\mathrm{P}_{2} \mathrm{O}_{5}$ & $\mathrm{~K}_{2} \mathrm{O}$ & & $\mathrm{Mg}$ & OM & $\mathrm{OC}$ & $\mathrm{CaO}$ & $\mathrm{Na}$ & $\mathrm{Mn}$ & & $\mathrm{Fe}$ & $\mathrm{S}$ \\
\hline 0 & 0.00 & 0.00 & 0.00 & & 0.00 & 0.00 & 0.00 & 0.00 & 0.00 & 0.00 & & 0.00 & 0.00 \\
\hline 20 & 30.70 & 25.60 & 34.60 & & 13.60 & 325.00 & 180.00 & 11.00 & 5.20 & 1.50 & & 6.30 & 4.40 \\
\hline 40 & 61.40 & 51.20 & 69.20 & & 27.20 & 650.00 & 360.00 & 22.00 & 10.40 & 3.00 & & 12.60 & 8.80 \\
\hline 60 & 92.10 & 76.80 & 103.8 & & 40.80 & 970.00 & 540.00 & 33.00 & 15.60 & 4.50 & & 18.90 & 13.20 \\
\hline 80 & 122.80 & 102.40 & 138.4 & & 54.40 & 1300.00 & 720.00 & 44.00 & 20.80 & 6.00 & & 25.20 & 17.60 \\
\hline
\end{tabular}

Note. $\mathrm{pH}$ in $\mathrm{CaCl}_{2}$; EC: Electrical conductivity; OM: Organic matter; OC: Organic carbon.

At planting, parts of the plant stem were distributed in a continuous, consecutive manner in the planting furrows at a depth of $0.10 \mathrm{~m}$ and later cut at every $0.40 \mathrm{~m}$. Experimental plots were composed of four furrows at a 
spacing of $1.0 \mathrm{~m}$ between rows and $3 \mathrm{~m}$ length, for a total of $12 \mathrm{~m}^{2}$ per plot. A useful area of $4 \mathrm{~m}^{2}$ was marked off in the center of each plot.

Irrigation was performed using a surface drip system with lateral lines (PELBD DN16) along each plant row. Drip nozzles with a discharge of $4.0 \mathrm{~L} \mathrm{~h}^{-1}$ and $100 \mathrm{KPa}$ pressure were installed every $0.60 \mathrm{~m}$ only in the plots with water replacement. A pressure regulating valve, model PRLG-15, and a pressure gauge at the beginning of the experimental area, for better control and uniformity of the system, were also installed.

Irrigation was carried out based on ETo, calculated daily by the Penman Monteith method (Allen, Pereira, Raes, \& Smith, 1998) and meteorological data were obtained from an automatic system, Davis Vantage Pro2 (Figure $1)$.

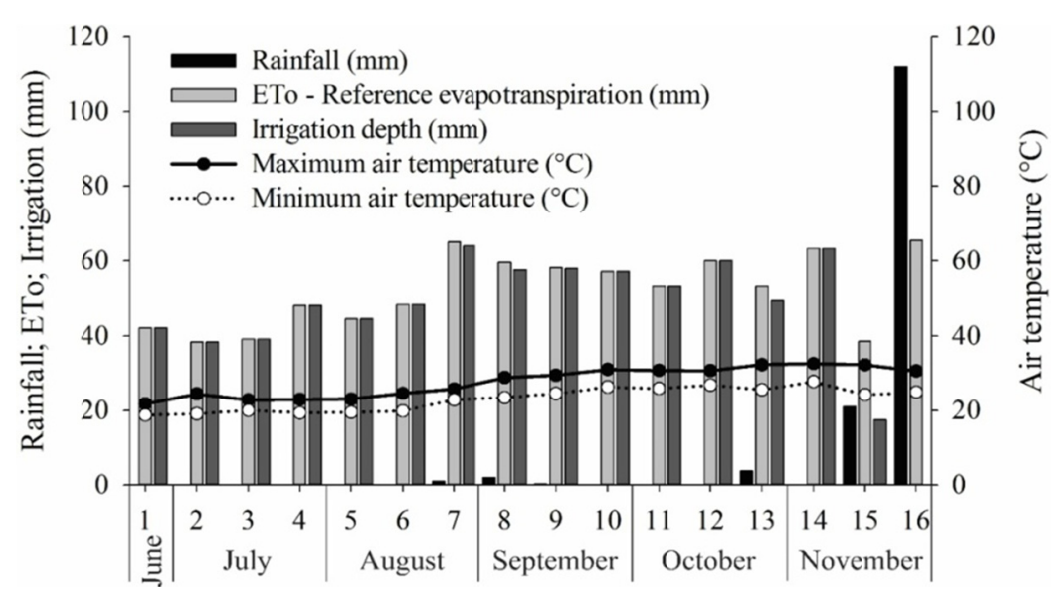

Figure 1. Rainfall, reference evapotranspiration (ETo), and accumulated irrigation water depth every ten days, and maximum and minimum temperature during the field experiment

\subsection{Data Collection}

Data on yield, leaf area index (LAI), and chlorophyll and macro- and micronutrient leaf content were obtained at 80 days after the beginning of each crop.

Fresh matter yield was determined in the useful area by cutting the plants at $0.40 \mathrm{~m}$ from the ground, with subsequent weighing. A representative subsampling of the fresh matter was taken for evaluation of dry matter. This subsample was weighed, placed in a kraft paper bag, and then placed in a forced air circulation laboratory oven with a mean temperature of $60{ }^{\circ} \mathrm{C}$ until achieving constant weight and then weighed to calculate the concentration of dry matter. Morphological composition was estimated by separating leaves and stems from five representative shoots of the sample. These fractions were weighed and dried, as performed for dry matter. The values obtained were extrapolated to $\mathrm{kg} \mathrm{ha}^{-1}$.

The LAI was obtained through the ratio between the dry matter of five leaves, their area, and the total dry matter of the leaves (Eze, 1973). The fourth fully expanded leaves, counting from the top to the base of the stem, were collected from five plants per plot. To obtain the area of the five leaves, the software Image Pro Plus ${ }^{\circledR}$ was used.

The total chlorophyll and chlorophyll $a$ and $b$ content was determined with a chlorophyll meter (ClorofiLOG, CFL 1030, FALKER), operated according to manufacturer's specifications. In the measurements, the fourth fully expanded leaf, counting from the top to the base of the stem, exposed to sunlight, was used from ten plants per plot to obtain the simple arithmetic average of the chlorophyll contents.

The leaf contents of $\mathrm{N}, \mathrm{P}, \mathrm{K}, \mathrm{Ca}, \mathrm{Mg}, \mathrm{S}, \mathrm{B}, \mathrm{Cu}, \mathrm{Fe}, \mathrm{Mn}$, and $\mathrm{Zn}$ were determined through collecting the fourth fully expanded leaf, counting from the tip to the base of the stems, from ten plants chosen at random within the useful area of each plot. The samples were taken to the laboratory, dried in a forced air circulation oven at $65^{\circ} \mathrm{C}$ until constant weight, ground in a Wiley mill, and sieved (sieve of $2 \mathrm{~mm}$ ), for later extraction by nitric-perchloric digestion ( $\mathrm{P}, \mathrm{K}, \mathrm{Ca}, \mathrm{Mg}, \mathrm{S}, \mathrm{Cu}, \mathrm{Fe}, \mathrm{Mn}$, and $\mathrm{Zn}$ ), sulfuric acid digestion $(\mathrm{N})$, and calcination in a muffle furnace (B), as described by Silva (2009). The N contents were determined by Semi-Micro-Kjeldahl and the other nutrients by atomic absorption spectrophotometry (Silva, 2009). 
The data of plant height were obtained at $30,45,60,75$, and 80 days after cutting for uniformity-five plants within the useful area of each plot were measured, and subsequently, the simple arithmetic average for the plot was determined. The growth rate was estimated by the final height minus the residue $(0.40 \mathrm{~m})$, divided by the time of growth (80 days).

\subsection{Statistical Analysis}

The data were subjected to analysis of variance by the $\mathrm{F}$ test at the level of $5 \%$ probability of error, and in cases of significance, regression analysis was carried out for the biofertilizer application rates through the statistical program R-plus ${ }^{\circledR}$ 3.2.1 1 from the Epi 1.1.18 library (R Foundation for Statistical Computing, Vienna, Austria, http:// www.r-project.org).

\section{Results}

\subsection{Productive aspects of Mexican Sunflower (Tithonia diversifolia)}

The water regime had a significant influence $(\mathrm{p} \leq 0.05)$ on the yield variables of Mexican Sunflower. The application rates of biofertilizer and the interaction among the factors did not influence $(p>0.05)$ the fresh and dry matter of Mexican Sunflower. Supplying water to the plants, through irrigation, led to the greatest yield gains, differing from the non-irrigated system by $560 \%$ and $470 \%$, in the first cutting, and $139 \%$ and $158 \%$ in the second cutting for the fresh matter and dry matter variables, respectively (Figure 2).

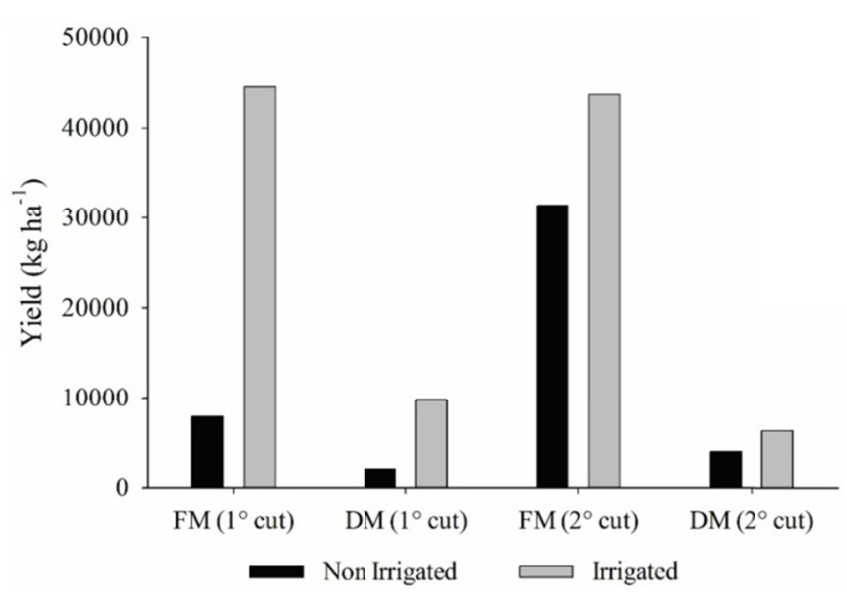

Figure 2. Fresh matter (FM) and dry matter (DM) yield of Mexican Sunflower (Tithonia diversifolia) as a function of water regime in two consecutive 80-days growth periods

The plant height of Mexican Sunflower was greater $(p \leq 0.01)$ in the irrigated crops in comparison to the non-irrigated at 45, 60, 75 and 80 days after cutting for uniformity in the first cutting and at 30, 45, 60, 75 and 80 days after cutting for uniformity in the second cutting (Figure 3). The growth rate of irrigated and non-irrigated Mexican Sunflower was 1.33 and $0.39 \mathrm{~cm} \mathrm{day}^{-1}$, respectively, in the first cutting, and 1.13 and $0.82 \mathrm{~cm} \mathrm{day}^{-1}$ in the irrigated and non-irrigated treatments of the second cutting, respectively. 

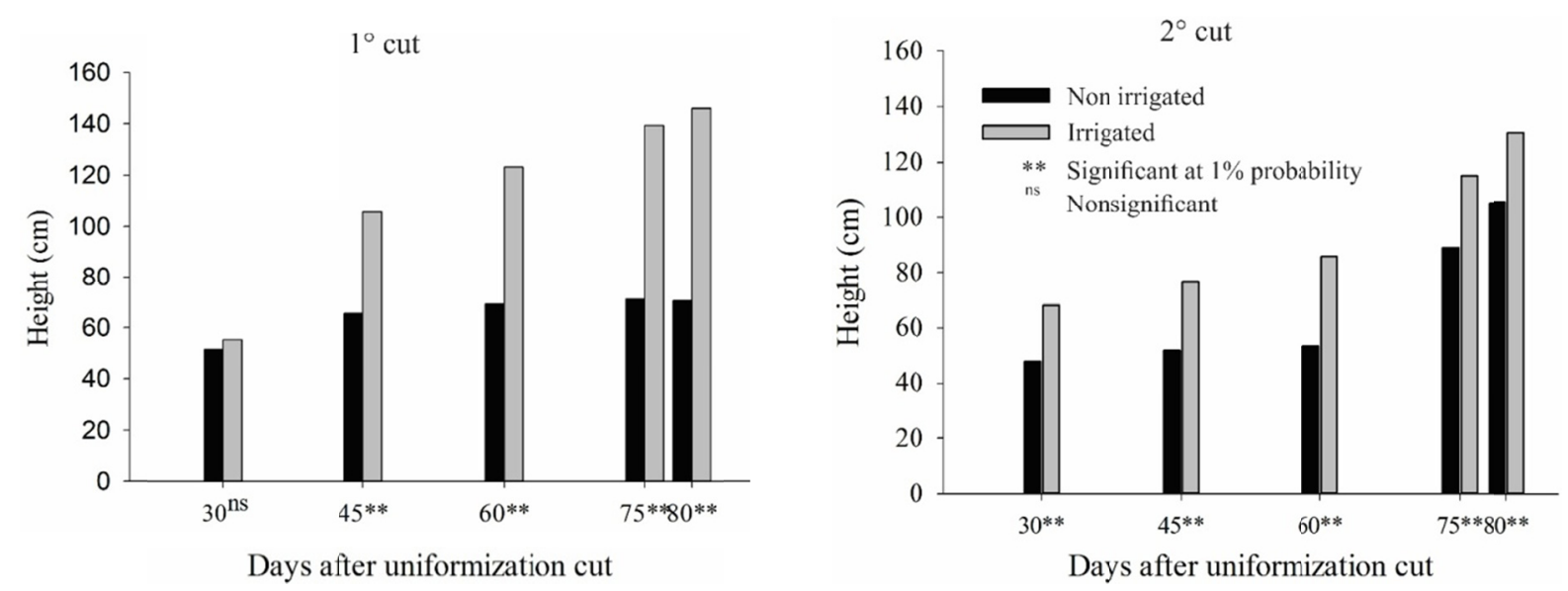

Figure 3. Height of Mexican Sunflower (Tithonia diversifolia) at 30, 45, 60, 75 and 80 days after cutting for uniformity in two consecutive crops

The leaf area index (LAI) was significantly influenced $(\mathrm{p} \leq 0.05)$ by the irrigation factor only in the first cutting. The irrigated plants had an LAI, on average, $187 \%$ superior to the non-irrigated treatments (Figure 4).

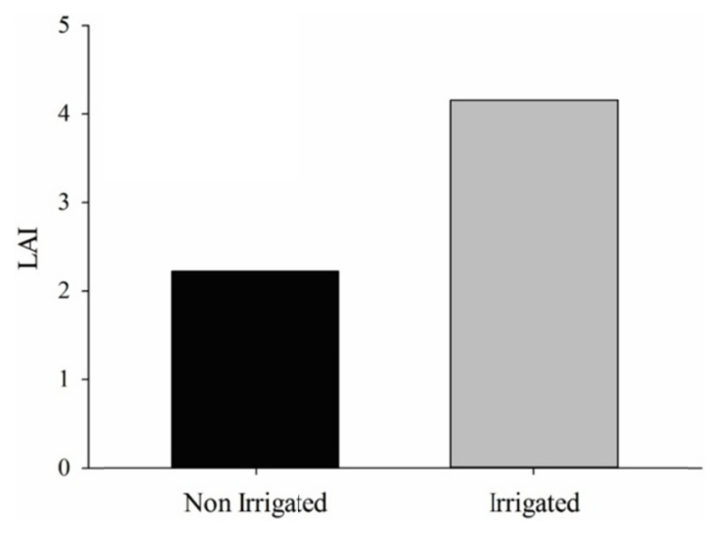

Figure 4. Leaf area index (LAI) of Mexican Sunflower (Tithonia diversifolia) in irrigated crop system and in a dryland system

\subsection{Leaf chlorophyll contents}

The greater quantity of fertilizer available in the irrigated soil resulted in mean increases in the two cuttings from 28.54 to 36.25 (Figures 5A and 5B), 23.35 to 29.39 (Figures 5C and 5D), and 5.29 to 7.73 (Figures 5E and 5F), with gains of 27.02, 25.87, and $46.03 \%$ in the contents of total chlorophyll and of chlorophyll $a$ and $b$ between plants fertilized with 0 and $160 \mathrm{~m}^{3} \mathrm{ha}^{-1}$ of biofertilizer, respectively. In the non-irrigated treatments, the biofertilizer application rates did not have an influence on total chlorophyll and chlorophyll $a$ and $b$ contents; their measurements in the two cuttings corresponded to 41.92, 31.88, and 10.03, respectively (Figures 5A-5F). The values of total chlorophyll and of chlorophyll $a$ and $b$ in the treatments without irrigation were greater than those shown in the irrigated treatments (Figures 5A-5F). 
$1^{\circ}$ cut

A.

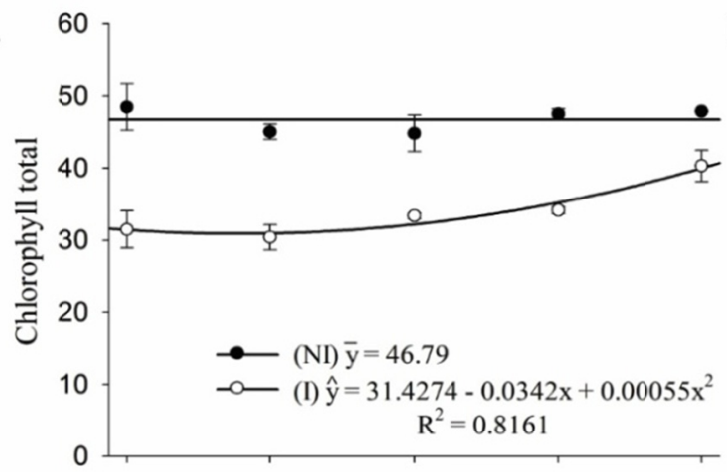

C.

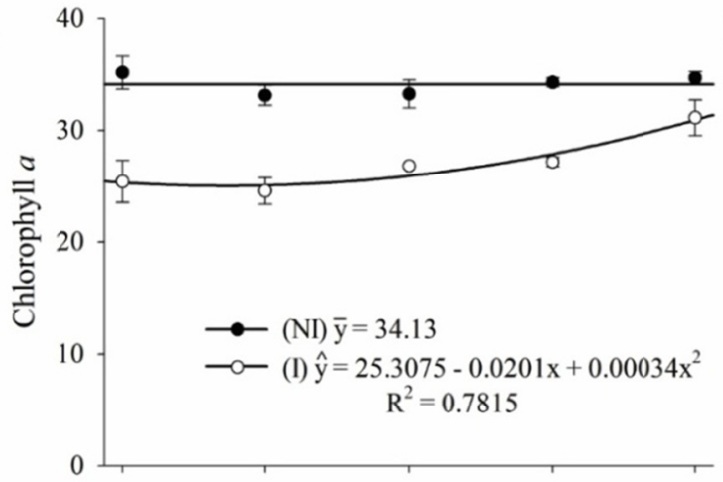

$2^{\circ}$ cut
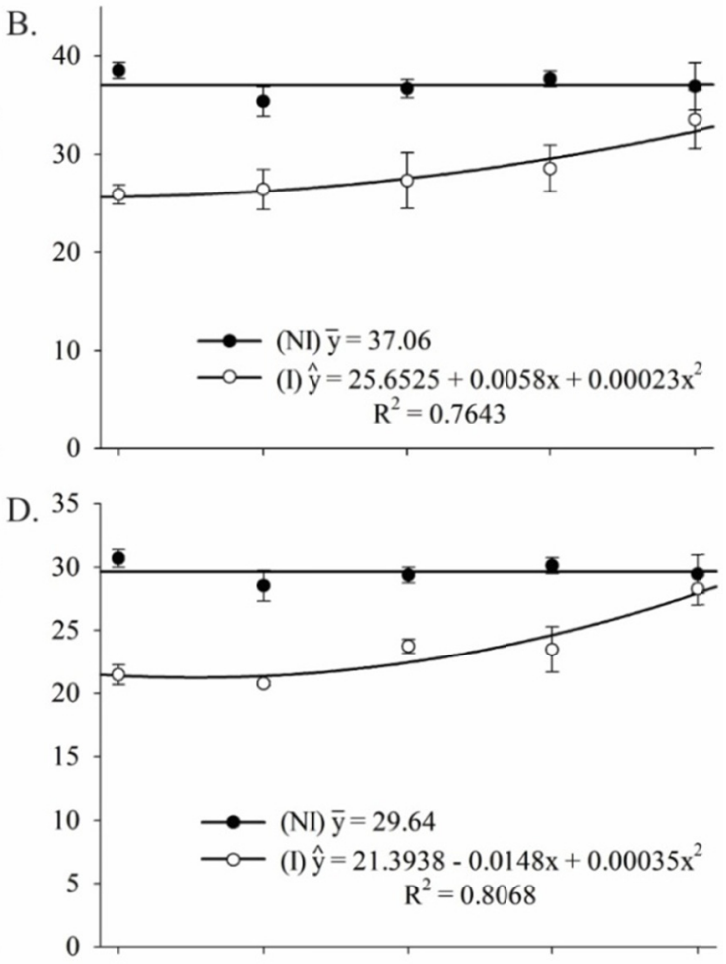

E.

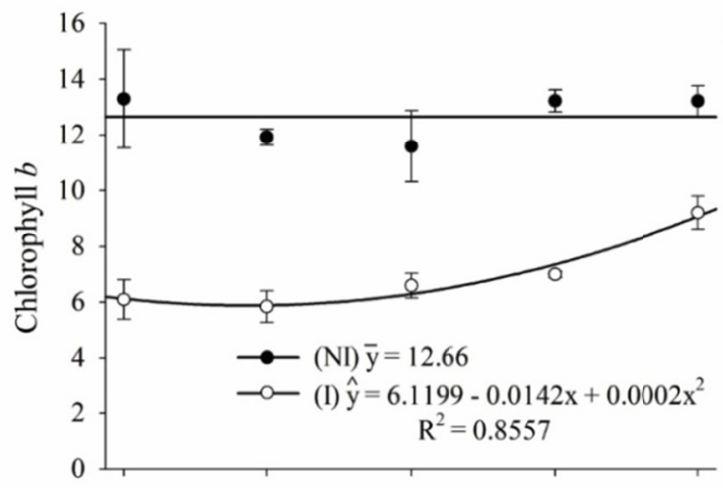

F. 10

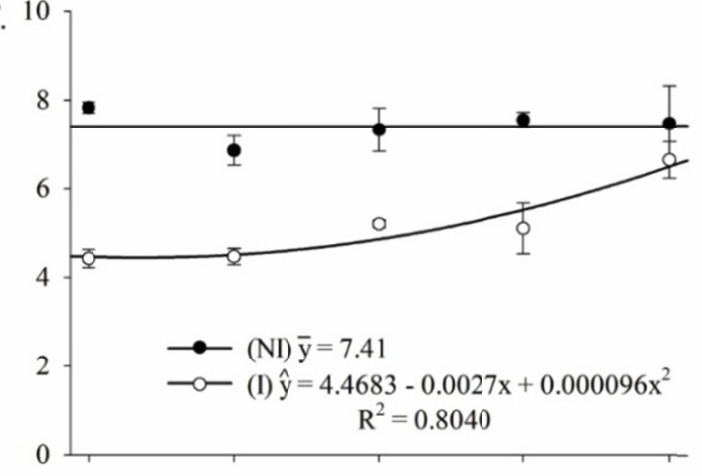

G.

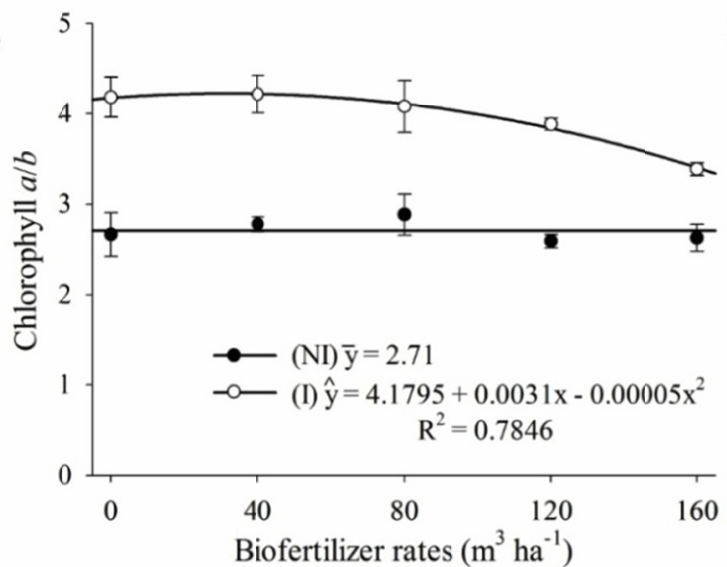

Figure 5. Leaf contents of total chlorophyll (A and B), chlorophyll $a$ (C and D), chlorophyll $b$ (E and F), and the chlorophyll $a / b$ ratio $(\mathrm{G}$ and $\mathrm{H}$ ) of Mexican Sunflower (Tithonia diversifolia) fertilized with increasing application rates of bovine biofertilizer in an irrigated (I) and non-irrigated (NI) system, 
The values of the chlorophyll $a / b$ ratio of the Mexican Sunflower plants obtained in the first cutting (Figure 5G) increased in the irrigated crop up to the application rate of bovine fertilizer of $31.00 \mathrm{~m}^{3} \mathrm{ha}^{-1}$. As of this value, a reduction was observed in the chlorophyll $a / b$ ratio of the leaves with the increase in fertilization, with the lowest value, 3.39, for the bovine biofertilizer application rate of $160 \mathrm{~m}^{3} \mathrm{ha}^{-1}$. In the second cutting, the values of the chlorophyll $a / b$ ratio in the leaves (Figure $5 \mathrm{H}$ ) showed a decreasing response with the increase in fertilization; the highest value found was 4.87 and the lowest was 4.31, in reference to the application rates of 0 and $160 \mathrm{~m}^{3}$ $\mathrm{ha}^{-1}$, respectively. However, under dryland conditions, the chlorophyll $a / b$ ratio in the leaves of Mexican Sunflower was an average of 3.36 in the two cuttings, regardless of the amount of biofertilizer applied to the soil.

\subsection{Nutritional Aspects of Mexican Sunflower (Tithonia diversifolia)}

An interaction was found between the irrigation and bovine biofertilizer application rate factors for leaf $\mathrm{K}$ and Mg contents of Mexican Sunflower in the second cutting of Mexican Sunflower (160 days); however, regression models were not obtained that fit the biological phenomenon. Fertilization with bovine biofertilizer significantly $(p \leq 0.05)$ influenced only Ca leaf content in the first cutting of Mexican Sunflower (80 days); however, regression models that fit the biological phenomenon were likewise not obtained. The presence or absence of irrigation had a significant $(\mathrm{p} \leq 0.01)$ effect on leaf content of N, P, Mn, and B at 80 and 160 days; K, Ca, and $\mathrm{Zn}$ at 80 days; and $\mathrm{S}$ and $\mathrm{Cu}$ at 160 days. The water regime also had a significant effect on Fe leaf content at 160 days, and $\mathrm{Cu}$ at 80 days, however, with a level of significance of 5\% (Table 2). 
Table 2. Macro and micronutrient content in leaves of Mexican Sunflower (Tithonia diversifolia) in two consecutive cuttings in response to different water regimes

\begin{tabular}{|c|c|c|c|c|c|c|c|c|c|c|c|c|}
\hline \multirow{2}{*}{\multicolumn{2}{|c|}{$\begin{array}{l}\text { BFR } \\
\mathrm{m}^{3} \mathrm{ha}^{-1}\end{array}$}} & $\mathrm{~N}$ & $\mathrm{P}$ & $\mathrm{K}$ & $\mathrm{Ca}$ & $\mathrm{Mg}$ & $\mathrm{S}$ & $\mathrm{Zn}$ & $\mathrm{Fe}$ & $\mathrm{Mn}$ & $\mathrm{Cu}$ & B \\
\hline & & \multicolumn{6}{|c|}{--------------------- dag kg'-1 ---------------------- } & \multicolumn{5}{|c|}{---------------- mg kg ${ }^{-1}$---------------- } \\
\hline \multicolumn{13}{|c|}{$1^{\circ}$ Cultivation (80 days) } \\
\hline \multirow{6}{*}{ 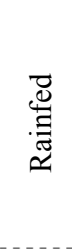 } & 0 & 3.1 & 0.1 & 2.1 & 2.2 & 0.3 & 0.2 & 13.0 & 440.0 & 156.0 & 2.7 & 67.5 \\
\hline & 40 & 3.2 & 0.1 & 2.1 & 2.5 & 0.3 & 0.2 & 18.0 & 383.3 & 124.0 & 3.0 & 66.1 \\
\hline & 80 & 2.9 & 0.1 & 2.0 & 2.9 & 0.3 & 0.2 & 14.0 & 338.7 & 126.3 & 2.7 & 76.7 \\
\hline & 120 & 3.2 & 0.1 & 2.0 & 2.5 & 0.3 & 0.2 & 16.0 & 378.0 & 163.3 & 3.0 & 60.0 \\
\hline & 160 & 3.2 & 0.1 & 2.2 & 2.3 & 0.3 & 0.2 & 15.7 & 307.3 & 109.0 & 2.7 & 60.4 \\
\hline & Mean & $3.1 \mathrm{a}$ & $0.1 \mathrm{~b}$ & $2.1 \mathrm{~b}$ & $2.5 \mathrm{a}$ & $0.3 \mathrm{a}$ & $0.2 \mathrm{a}$ & $15.3 \mathrm{~b}$ & $369.5 \mathrm{a}$ & $135.7 \mathrm{a}$ & $2.8 \mathrm{~b}$ & $66.1 \mathrm{~b}$ \\
\hline \multirow{6}{*}{ 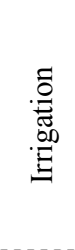 } & 0 & 2.3 & 0.15 & 2.57 & 1.8 & 0.3 & 0.16 & 19.7 & 302.0 & 71.0 & 3.3 & 113.7 \\
\hline & 40 & 2.2 & 0.17 & 2.70 & 1.7 & 0.3 & 0.17 & 22.7 & 350.0 & 65.0 & 3.7 & 118.9 \\
\hline & 80 & 2.5 & 0.17 & 2.70 & 1.9 & 0.3 & 0.21 & 21.0 & 361.0 & 72.0 & 3.7 & 113.7 \\
\hline & 120 & 2.4 & 0.17 & 2.63 & 1.8 & 0.3 & 0.16 & 22.3 & 341.3 & 63.0 & 3.0 & 112.2 \\
\hline & 160 & 2.7 & 0.16 & 2.77 & 1.8 & 0.3 & 0.20 & 20.0 & 299.3 & 78.7 & 3.7 & 116.1 \\
\hline & Mean & $2.4 \mathrm{~b}$ & $0.17 \mathrm{a}$ & $2.67 \mathrm{a}$ & $1.8 \mathrm{~b}$ & $0.3 \mathrm{a}$ & $0.18 \mathrm{a}$ & $21.1 \mathrm{a}$ & $330.7 \mathrm{a}$ & $69.9 \mathrm{~b}$ & $3.5 \mathrm{a}$ & $114.9 \mathrm{a}$ \\
\hline \multicolumn{13}{|c|}{ F-test } \\
\hline \multicolumn{2}{|c|}{ Regime (a) } & $23.5 * *$ & $18.1 * *$ & $24.5^{* *}$ & $112.1 * *$ & $1.6^{\mathrm{NS}}$ & $0.002^{\mathrm{NS}}$ & $17.6^{* *}$ & $2.3^{\mathrm{NS}}$ & $28.2 * *$ & $5.9^{*}$ & $123.9 * *$ \\
\hline \multicolumn{2}{|c|}{ Rates (b) } & $0.3^{\mathrm{NS}}$ & $0.2^{\mathrm{NS}}$ & $0.3^{\mathrm{NS}}$ & $4.1^{*}$ & $0.7^{\mathrm{NS}}$ & $0.7^{\mathrm{NS}}$ & $1.0^{\mathrm{NS}}$ & $0.9^{\mathrm{NS}}$ & $0.5^{\mathrm{NS}}$ & $0.2^{\mathrm{NS}}$ & $0.5^{\mathrm{NS}}$ \\
\hline \multicolumn{2}{|l|}{$a \times b$} & $0.5^{\mathrm{NS}}$ & $0.5^{\mathrm{NS}}$ & $0.1^{\mathrm{NS}}$ & $2.8^{\mathrm{NS}}$ & $0.5^{\mathrm{NS}}$ & $1.4^{\mathrm{NS}}$ & $0.1^{\mathrm{NS}}$ & $1.1^{\mathrm{NS}}$ & $1.0^{\mathrm{NS}}$ & $0.4^{\mathrm{NS}}$ & $0.6^{\mathrm{NS}}$ \\
\hline \multicolumn{2}{|c|}{ General mean } & 2.8 & 0.1 & 2.4 & 2.1 & 0.3 & 0.2 & 18.2 & 350.1 & 102,8 & 3.1 & 90.5 \\
\hline \multicolumn{2}{|c|}{ SD } & 0.4 & 0.02 & 0.3 & 0.2 & 0.05 & 0.04 & 3.8 & 69.6 & 33.9 & 0.7 & 12.0 \\
\hline \multicolumn{2}{|l|}{$\mathrm{CV} \%$} & 13.9 & 12.2 & 13.5 & 8.3 & 17.7 & 21.1 & 20.8 & 19.9 & 33.0 & 24.0 & 13.3 \\
\hline \multicolumn{13}{|c|}{$2^{\circ}$ Cultivation (160 days) } \\
\hline \multirow{6}{*}{ 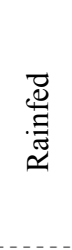 } & 0 & 4.5 & 0.3 & 2.2 & 1.8 & 0.4 & 0.2 & 58.0 & 93.3 & 41.7 & 14.0 & 77.1 \\
\hline & 40 & 4.4 & 0.3 & 2.6 & 1.9 & 0.3 & 0.2 & 56.3 & 84.7 & 31.3 & 13.0 & 83.7 \\
\hline & 80 & 4.3 & 0.3 & 2.6 & 1.7 & 0.4 & 0.3 & 60.7 & 98.3 & 29.0 & 12.7 & 80.5 \\
\hline & 120 & 4.7 & 0.3 & 2.5 & 1.9 & 0.4 & 0.3 & 64.0 & 93.0 & 34.0 & 15.0 & 73.3 \\
\hline & 160 & 4.6 & 0.3 & 2.4 & 1.9 & 0.4 & 0.2 & 71.7 & 87.3 & 28.7 & 15.7 & 79.2 \\
\hline & Mean & $4.5 \mathrm{a}$ & $0.3 \mathrm{a}$ & $2.4 \mathrm{a}$ & $1.8 \mathrm{a}$ & $0.4 \mathrm{a}$ & $0.2 \mathrm{a}$ & $62.1 \mathrm{a}$ & $91.3 \mathrm{a}$ & $32.9 \mathrm{a}$ & $14.1 \mathrm{a}$ & $78.8 \mathrm{~b}$ \\
\hline \multirow{6}{*}{ 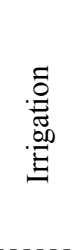 } & 0 & 2.9 & 0.2 & 2.8 & 2.0 & 0.4 & 0.2 & 61.0 & 77.0 & 22.3 & 7.0 & 116.1 \\
\hline & 40 & 2.7 & 0.2 & 2.3 & 1.9 & 0.4 & 0.2 & 59.7 & 86.7 & 22.7 & 4.7 & 115.2 \\
\hline & 80 & 3.2 & 0.2 & 2.2 & 1.9 & 0.4 & 0.2 & 57.3 & 79.3 & 23.0 & 5.3 & 108.0 \\
\hline & 120 & 2.8 & 0.2 & 2.3 & 1.8 & 0.4 & 0.1 & 58.3 & 78.3 & 20.7 & 5.7 & 113.5 \\
\hline & 160 & 3.5 & 0.2 & 2.4 & 1.9 & 0.4 & 0.2 & 54.7 & 91.7 & 26.7 & 6.7 & 121.1 \\
\hline & Mean & $3.0 \mathrm{~b}$ & $0.2 b$ & $2.4 \mathrm{a}$ & $1.9 \mathrm{a}$ & $0.4 \mathrm{a}$ & $0.2 \mathrm{a}$ & $58.2 \mathrm{a}$ & $82.6 \mathrm{~b}$ & $23.1 \mathrm{~b}$ & $5.9 \mathrm{~b}$ & $114.8 \mathrm{a}$ \\
\hline \multicolumn{13}{|c|}{ F-test } \\
\hline \multicolumn{2}{|c|}{ Regime (a) } & $122.8 * *$ & $38.7 * *$ & $0.2^{\mathrm{NS}}$ & $0.9^{\mathrm{NS}}$ & $0.9^{\mathrm{NS}}$ & $52.8 * *$ & $2.6^{\mathrm{NS}}$ & $5.5^{*}$ & $31.0 * *$ & $122.8 * *$ & $89.4 * *$ \\
\hline \multicolumn{2}{|c|}{ Rates (b) } & $1.3^{\mathrm{NS}}$ & $2.0^{\mathrm{NS}}$ & $0.3^{\mathrm{NS}}$ & $0.2^{\mathrm{NS}}$ & $2.2^{\mathrm{NS}}$ & $1.2^{\mathrm{NS}}$ & $0.6^{\mathrm{NS}}$ & $0.2^{\mathrm{NS}}$ & $1.4^{\mathrm{NS}}$ & $1.5^{\mathrm{NS}}$ & $0.5^{\mathrm{NS}}$ \\
\hline \multicolumn{2}{|l|}{$a \times b$} & $0.3^{\mathrm{NS}}$ & $1.9^{\mathrm{NS}}$ & $3.8^{*}$ & $0.4^{\mathrm{NS}}$ & $4.3^{*}$ & $1.4^{\mathrm{NS}}$ & $2.3^{\mathrm{NS}}$ & $1.8^{\mathrm{NS}}$ & $2.9^{\mathrm{NS}}$ & $0.4^{\mathrm{NS}}$ & $0.5^{\mathrm{NS}}$ \\
\hline \multicolumn{2}{|c|}{ General mean } & 3.8 & 0.3 & 2.4 & 1.9 & 0.4 & 0.2 & 60.2 & 87.0 & 28.0 & 10.0 & 96.8 \\
\hline \multicolumn{2}{|l|}{ SD } & 0.4 & 0.02 & 0.2 & 0.2 & 0.03 & 0.03 & 6.6 & 10.1 & 4.9 & 2.0 & 10.4 \\
\hline $\mathrm{CV} \%$ & & 9.8 & 9.6 & 10.3 & 11.1 & 7.9 & 13.9 & 11.0 & 11.7 & 17.3 & 20.3 & 10.8 \\
\hline
\end{tabular}

Note. **significant at $1 \%$ probability, *significant at $5 \%$ probability, ${ }^{\mathrm{NS}}$ nonsignificant. BFR: biofertilizer rates, SD: Standard Deviation, CV: coefficient of variation. Means followed by the same letter in the column do not differ at the 0.05 probability level by the $\mathrm{F}$ test.

Irrigation contributed to an increase in the $\mathrm{P}$ and $\mathrm{K}$ content in the leaves of Mexican Sunflower at 80 days, differing from the non-irrigated treatments by 0.03 and $0.58 \mathrm{dag} \mathrm{kg}^{-1}$, respectively (Table 2).

The leaves of Mexican Sunflower grown in a non-irrigated system had greater content of $\mathrm{N}$ at 80 and 160 days, of $\mathrm{Ca}$ at 80 days, and of $\mathrm{P}$ and $\mathrm{S}$ at 160 days, resulting in mean gains of 0.68 and $1.48 \mathrm{dag} \mathrm{kg}^{-1}$ of $\mathrm{N}$ in the first and second cutting, respectively, of $0.68 \mathrm{dag} \mathrm{kg}^{-1}$ of Ca in the first cutting, and of $0.05 \mathrm{dag} \mathrm{kg}^{-1}$ of P and $0.08 \mathrm{dag}$ $\mathrm{kg}^{-1}$ of S in the second cutting (Table 2). 
Irrigation of Mexican Sunflower led to an increase in leaf contents of $\mathrm{Zn}$ and $\mathrm{Cu}$ at 80 days and of $\mathrm{B}$ at 80 and 160 days, resulting in mean increases of 5.80 and $0.67 \mathrm{mg} \mathrm{kg}^{-1}$ of $\mathrm{Zn}$ and $\mathrm{Cu}$, respectively, in the first cutting and of 48.78 and $36.00 \mathrm{mg} \mathrm{kg}^{-1}$ of $\mathrm{B}$ in the first and second cutting, respectively (Table 2).

Cultivation of Mexican Sunflower in a non-irrigated water regime exhibited higher leaf contents of $\mathrm{Fe}$ and $\mathrm{Cu}$ at 160 days, and of $\mathrm{Mn}$ at 80 and 160 days compared to the irrigated treatments, resulting in mean increases of 8.73 and $8.20 \mathrm{mg} \mathrm{kg}^{-1}$ of $\mathrm{Fe}$ and $\mathrm{Cu}$, respectively, in the second cutting, and of 65.80 and $9.86 \mathrm{mg} \mathrm{kg}^{-1}$ of $\mathrm{Mn}$ in the first and second cutting, respectively (Table 2 ).

\section{Discussion}

The irrigated plants had mean values of fresh matter and dry matter of 44569.3 and $9805.3 \mathrm{~kg} \mathrm{ha}^{-1}$ in the first cutting and 43690.0 and $6355.3 \mathrm{~kg} \mathrm{ha}^{-1}$ in the second cutting, respectively (Figure 2). A similar result was reported by Mahecha and Rosales (2005), who observed yield between 30000 and $70000 \mathrm{~kg} \mathrm{ha}^{-1}$ of fresh forage; the result was greater than that found by Sao et al. (2010), who observed mean yield throughout the year of 24 $570 \mathrm{~kg} \mathrm{ha}^{-1}$ of fresh matter in a crop in Vietnam.

Non-irrigated plants had fresh matter values of 7958.7 and $31359.3 \mathrm{~kg} \mathrm{ha}^{-1}$ and dry matter values of 2087.3 and $4010.0 \mathrm{~kg} \mathrm{ha}^{-1}$ in the first and second cutting, respectively (Figure 2). This response pattern can be explained by the fact that the plants of the first crop grew under dry conditions, with accumulated rainfall in this period of 3 $\mathrm{mm}$ (Figure 1). During the second crop, the non-irrigated plants received a water depth through rainfall of $136.82 \mathrm{~mm}$ (Figure 1), showing the potential and the need for irrigation for greater forage production in the time of water scarcity. In addition, it is important to highlight the ability for regrowth and the tolerance of Mexican Sunflower to the cutting management practice adopted in the experiment, as well as its survival in the dry period of the year.

The high natural fertility of the soil used in this trial may have contributed to the lack of yield response of Mexican Sunflower in relation to the increase in the application rates of bovine biofertilizer, which suggests lower demands of the crop in regard to availability of soil nutrients. Forage crops such as Urochloa decumbens, U. humidicola, Paspalum atratum, P. plicatulum, and Andropogon gayanus are also not demanding in regard to soil fertility (Fonseca \& Martuscello, 2011); however, they do not have the same bromatological quality as Mexican Sunflower (Fonseca \& Martuscello, 2011; Odedire \& Oloidi, 2014). The favorable bromatological characteristics of Mexican Sunflower (Osuga et al., 2012; Odedire \& Oloidi, 2014), together with its hardiness, found in this study, places this plant as a potential forage crop for semi-arid regions. Future studies should be carried out to evaluate the species in regard to adaptation to different soils.

The increase in leaf area of forage plants, in addition to allowing greater interception of light, favor animal performance since this organ contains higher nutrient contents and higher digestibility (Xiao et al., 2015).

Humphreys (1991) reports that, in general, in pastures, values of critical LAI are from 3 to 5, and in this range, interception of light is approximately $95 \%$. Within this critical value, the growth rate of any forage crop would be near its maximum value (Brougham, 1956; Borges, Da Silva, Lucas, \& Da Silva, 2011). In the first cutting, the LAI values found in the irrigated and non-irrigated Mexican Sunflower plants were 4.16 and 2.22, respectively, showing that only the irrigated plants achieved critical LAI. Thus, it is possible to infer that the mean cutting height of Mexican Sunflower in non-irrigated and irrigated crops is around 0.9 and $1.4 \mathrm{~m}$, respectively. Nevertheless, it should be noted that the reference data found in the literature (Borges et al., 2011) refer to forage grasses, whose shoot structure is drastically different than Mexican Sunflower.

The positive effects of irrigation on forage crops have been confirmed by various studies (Ul-Allah et al., 2015; Xiao et al., 2015). Reduction in growth and development can be considered a pattern of natural response of plants to water deficit. Lack of water available to plants promotes a decline in cell turgor pressure, leading to lower leaf expansion (Taiz \& Zeiger, 2013). In addition, low availability of water in the soil hinders nutrient uptake. Nevertheless, in this study, interaction between the factors of irrigation and biofertilizer application rate was not observed for the variables of growth, development, and yield, showing that availability of water in the soil is determinant and primary in relation to nutrient uptake.

The increase in the biofertilizer application rate favored the production of total chlorophyll and of chlorophyll $a$ and $b$ in the irrigated plants (Figures 5A-5F). A similar response was reported by Ouni et al. (2014), and Széles, Megyes, and Nagy (2012), who observed that the increase in fertilizer application rates supplied to the plant led to an increase in the photosynthetic activity of maize (Zea mays L.), barley (Hordeum vulgare), and rabbitsfoot grass (Polypogon monspeliensis). 
The increase in the nitrogen content in the soil available to plants contributes to the increase in the content of leaf chlorophyll since this element is part of the chlorophyll molecule, and it also contributes to the photosynthetic activity of plants in general (Taiz \& Zeiger, 2013). In comparison, the effects are similar to those reported by Széles et al. (2012) in maize, who observed that fertilization leads to an increase in chlorophyll contents.

In the non-irrigated treatments, the biofertilizer application rates did not have an influence on total chlorophyll and chlorophyll $a$ and $b$ contents (Figures 5A-5F). This behavior can be explained by the Law of the Minimum (Paris, 1992) because when fertilizer is applied at an amount sufficient for increasing leaf chlorophyll content, it comes to be limited by low availability of water in the soil.

The values of total chlorophyll and of chlorophyll $a$ and $b$ in the treatments without irrigation were greater than those shown in the irrigated treatments (Figures 5A-5F). According to Shahabi, Malakouti, and Fallahi (2005), high bicarbonate concentrations in the rhizosphere are associated with high levels of $\mathrm{pH}$ in the cytoplasm, an increase in root respiration, and activity of the cytochrome oxidase enzyme, as well as reduction in chlorophyll synthesis. Consequently, the addition of bicarbonate to the soil by means of irrigation water leads to deficiency in leaf chlorophyll content, which was observed in this study and which can be explained by the bicarbonate content $\left(452.80 \mathrm{mg} \mathrm{L}^{-1}\right)$ in the water used for irrigation of Mexican Sunflower.

In the plants fertilized with higher application rates of bovine biofertilizer in irrigated cropping, photosynthetic activity was favored, in comparison to those fertilized with low application rates of this organic fertilizer. This finding result from higher contents of chlorophyll $b$ (Figures 5E and 5F) in relation to chlorophyll $a$ (Figure 5C and $5 \mathrm{D}$ ) and, consequently, reduction in the chlorophyll $a / b$ ratio (Figure $5 \mathrm{G}$ and $5 \mathrm{H}$ ). The decline in this ratio, according to Cancellier et al. (2011), is due to higher contents of chlorophyll $b$ in the leaves, thus increasing the efficacy of photosynthetic reactions. Chlorophyll $a$ actively participates in the first photochemical process of photosynthesis, while the main function of chlorophyll $b$ is absorption of light in the wavelength spectrum not absorbable by chlorophyll $a$ (Taiz \& Zeiger, 2013).

An increase in leaf contents of $\mathrm{P}, \mathrm{K}, \mathrm{Zn}, \mathrm{Cu}$, and $\mathrm{B}$ as a result of irrigation (Table 2) were also found by other authors (Gunes et al., 2006; Zhang, Yao, Li, Hu, \& Chen, 2014). Water is probably the most important factor in the process of nutrient uptake from the soil and transport of essential elements through the xylem and phloem (Taiz \& Zeiger, 2013).

The high contents of bicarbonate found in the irrigation water used in this study ( $453 \mathrm{mg} \mathrm{L}^{-1}$ ) may have reduced the solubility of some nutrients in the soil and caused lower uptake and contents of $\mathrm{N}, \mathrm{P}, \mathrm{Ca} \mathrm{S}, \mathrm{Fe}, \mathrm{Mn}$, and $\mathrm{Cu}$ in the plants of the irrigated system in comparison to those of the non-irrigated treatments (Table 2). In general, it is acceptable for the bicarbonate content in irrigation water to be between 0 and $160 \mathrm{mg} \mathrm{L}^{-1}$ (Roosta, 2011).

The concept that bicarbonate can interfere in nutrient uptake by plants is not recent; however, the cell mechanisms through which such effect is manifested and how the bicarbonate interferes in the uptake and availability of each essential nutrient are not yet very clear. The relationship of increase in the bicarbonate content in the irrigation water with decrease in Fe leaf content is reported in the literature (Shahabi et al., 2005; Colla, Rouphael, Cardarelli, Salerno, \& Rea, 2010; Roosta, 2011); however, this connection in not well defined in regard to other nutrients. Leaf contents of $\mathrm{Mg}$ increased under high concentrations of $\mathrm{HCO}_{3}$ in the growth medium, as reported for apple (Shahabi et al., 2005), spinach (Assimakopoulou, 2006), and watermelon (Colla et al., 2010) crops. In tobacco, the Mg content remained unchanged (Pearce, Li, \& Bush, 1999) and in olives, it decreased (Guardia \& Alcantara, 2002), also under high concentrations of $\mathrm{HCO}_{3}$. Bicarbonate has also been considered the cause of Zn deficiency (Yang, Romheld, \& Marschner, 1993), as observed in apple (Shahabi et al., 2005), spinach (Assimakopoulou, 2006), and watermelon (Colla et al., 2010) plants.

High concentrations of $\mathrm{HCO}_{3}$ in the irrigation water promote an increase in soil $\mathrm{pH}$, which has an indirect effect on nutrient availability to plants (Roosta, 2011; White, 2012). In addition, the effect of high concentrations of $\mathrm{HCO}_{3}$ on a decrease in the root/shoot ratio has been reported, which brings about physiological disadvantages because, in addition to decreasing the soil volume exploited by the root system, the source/sink relationship is also reduced (Assimakopoulou, 2006; White, 2012; Taiz \& Zeiger, 2013).

With the results obtained in the present experiment, the yield potential of Mexican Sunflower when irrigated is shown; however, when cultivated in dryland, the species is able to survive without this resource, even when cut in a period of water restriction (Figure 1). In addition, in spite of having high concentration of nutrients, above all nitrogen, this plant seems not to make large demands in regard to soil fertility, considering that, in this trial, the incorporation of bovine biofertilizer did not result in gains in yield and plant growth. 
Thus, undertaking new studies on the nutritional demands of Mexican Sunflower in soils of tropical origin are of utmost importance for establishing fertilization recommendations. In regard to irrigated cultivation, it is important that new studies clarify the effect of application of irrigation water rich in bicarbonate on the quality of Mexican Sunflower when used as forage or green manure.

\section{Conclusions}

Fertilization with bovine biofertilizer does not favor yield, plant growth, and leaf content of nutrients of Mexican Sunflower (Tithonia diversifolia) in fertile soil.

Irrigation at a water depth of $100 \%$ of reference evapotranspiration promotes gains in yield, leaf area index, and height of Mexican Sunflower (Tithonia diversifolia).

The increase in the application rate of bovine biofertilizer favors total chlorophyll and chlorophyll $a$ and $b$ content in the leaves of Mexican Sunflower (Tithonia diversifolia).

Irrigation promotes higher contents of $\mathrm{K}, \mathrm{Zn}$, and B in Mexican Sunflower (Tithonia diversifolia) plants; however, it reduces leaf contents of $\mathrm{N}, \mathrm{Ca}, \mathrm{S}, \mathrm{Fe}$, and $\mathrm{Mn}$.

\section{Acknowledgments}

The authors thank Fundação de Amparo à Pesquisa do Estado de Minas Gerais (FAPEMIG) for financial support. Coordenação de Aperfeiçoamento de Pessoal de Nível Superior (CAPES-Brazil) and Conselho Nacional de Desenvolvimento Científico e Tecnológico (CNPq) for providing scholarships.

\section{References}

Ajayi, A. F., Farinu, G. O., Ojebiyi, O. O., \& Olayeni, T. B. (2007). Performance evaluation of male weaner rabbits fed diets containing graded levels of Blood-Wild Sunflower leaf meal mixture. World Journal of Agricultural Sciences, 3(2), 250-255.

Allen, R. G., Pereira, L. S., Raes, D., \& Smith, M. (1998). Crop evapotranspiration: Guide lines for computing crop evapotranspiration. Rome: FAO.

Assimakopoulou, A. (2006). Effect of iron supply and nitrogen form on growth, nutritional status and ferric reducing activity of spinach in nutrient solution culture. Scientia Horticulturae, 110(1), 21-29. https://doi.org/10.1016/j.scienta.2006.06.010

Borges, B. M. M. N., Da Silva, L. C., Lucas, F. T., \& Da Silva, W. J. (2011). Relação entre o fluxo luminoso interceptado em diferentes épocas no índice de área foliar de diferentes forrageiras. Semina: Ciências Agrárias, 32(4), 1589-1594. https://doi.org/10.5433/1679-0359.2011v32n4p1589

Brougham, R. M. (1956). Effect of intensity of defoliation on regrowth of pasture. Australian Journal of Agricultural Research, 7(5), 377-387. https://doi.org/10.1071/AR9560377

Cancellier, E. L., Barros, H. B., Kischel, E., Gonzaga, L. A. M., Brandão, D. R., \& Fidelis, R. R. (2011). Eficiência agronômica no uso de nitrogênio mineral por cultivares de arroz de terras altas. Agrária, 6(4), 650-656. https://doi.org/10.5039/agraria.v6i4a1420

Colla, G., Rouphael, Y., Cardarelli, M., Salerno, A., \& Rea, E. (2010). The effectiveness of grafting to improve alkalinity tolerance in watermelon. Environmental and Experimental Botany, 68(3), $283-291$. https://doi.org/10.1016/j.envexpbot.2009.12.005

Eze, J. M. (1973). The vegetative growth of Helianthus annuus and Phaseolus vulgaris as affected by seasonal factors in Freetown, Sierra Leone. Annals of Botany, 37(150), 315-329. https://doi.org/10.1093/oxford journals.aob.a084694

Fasuyi, A. O., \& Afolabi, A. A. (2013). Protein supplementation value of sun-dried ensiled sunflower (Tithonia diversifolia) in grower pigs: growth performance and nitrogen utilization. African Journal of Food Science, 7(9), 344-349. https://doi.org/10.5897/AJFS2013.1050

Fonseca, D. M., \& Martuscello, J. A. (2011). Plantas Forrageiras. Viçosa: UFV.

Guardia, M. D., \& Alcantara, E. (2002). Bicarbonate and low iron level increase root to total plant weight ratio in olive and peach rootstock. Journal of Plant Nutrition, 25(5), 1021-1032. https://doi.org/10.1081/ PLN-120003936

Gunes, A., Cicek, N., Inal, A., Alpaslan, M., Eraslan, F., Guneri, E., \& Guzelordu, T. (2006). Genotypic response of chickpea (Cicer arietinum L.) cultivars to drought stress implemented at pre- and post-anthesis stages 
and its relations with nutrient uptake and efficiency. Plant, Soil and Environment, 52(8), 368-376. https://doi.org/10.17221/3454-PSE

Humphreys, L. R. (1991). Tropical pasture utilization. New York, NY: Cambridge University Press. https://doi.org/10.1017/CBO9780511525810

Mahecha, L., \& Rosales, M. (2005). Valor nutricional delfollaje de Botón de Oro (Tithonia diversifolia [Hemsl]. Gray) en la producción animal en el trópico. Livestock Research for Rural Development, 17(9), 1.

Medina, M. L., \& Carreño, R. J. (1999). Evacuación del material foliar de rayo de sol como posible fuente de xantofilas. Agronomía Tropical, 49(4), 373-390.

Ministério da Agricultura, Pecuária e Abastecimento. (2007). Manual de métodos analíticos oficiais para fertilizante e corretivos. Brasilia, DF: Ministério da Agricultura, Pecuária e Abastecimento.

Odedire, J. A., \& Oloidi, F. F. (2014). Feeding Wild Sunflower (Tithonia Diversifolia Hemsl., A. Gray) to West African Dwarf Goats as a Dry Season Forage Supplement. World Journal of Agricultural Research, 2(6), 280-284. https://doi.org/10.12691/wjar-2-6-6

Osuga, I. M., Abdulrazak, S. A., Muleke, C. I., \& Fujihara, T. (2012). Potential nutritive value of various parts of wild sunflower (Tithonia diversifolia) as source of feed for ruminants in Kenya. Journal of Food, Agriculture \& Environment, 10(2), 632-635.

Ouni, Y., Naranjo, E. M., Lakhdar, A., Moreno, L. A., Abdelly, C., \& Barhoumi, Z. (2014). Municipal solid waste compost application improves the negative impact of saline soil in two forage species. Communications in Soil Science and Plant Analysis, 45(10), 1421-1434. https://doi.org/10.1080/00103624.2013.875209

Owoyele, V. B., Wuraola, C. O., Soladoye, A. O., \& Olaleye, S. B. (2004). Studies on the anti-inflammatory and analgesic properties of Tithonia diversifolia leaf extract. Journal of Ethnopharmacology, 90(2-3), $317-321$. https://doi.org/10.1016/j.jep.2003.10.010

Paris, Q. (1992). The return of von Liebig's 'Law of the Minimum'. Agronomy Journal, 84(6), 1040-1046. https://doi.org/10.2134/agronj1992.00021962008400060025x

Pearce, R. C., Li, Y., \& Bush, L. P. (1999). Calcium and bicarbonate effects on the growth and nutrient uptake of burley tobacco seedlings: float system. Journal of Plant Nutrition, 22(7), 1079-1090. https://doi.org/ $10.1080 / 01904169909365697$

Ramírez-Rivera, U., Sanginés-García, J. R., Escobedo-Mex, J. G., Cen-Chuc, F., Rivera-Lorca, J. A., \& Lara-Lara, P. E. (2010). Effect of diet inclusion of Tithonia diversifolia on feed intake, digestibility and nitrogen balance in tropical sheep. Agroforestry Systems, 80(2), 295-302. https://doi.org/10.1007/s10457 $-010-9320-0$

Reis, M. M., Cruz, L. R., Da Costa, G. A., Barros, R. E., \& Tuffi Santos, L. D. (2015). Potencial forrageiro de Tithonia diversifolia na alimentação animal. Caderno de Ciências Agrárias, 7(1), 233-245.

Ribeiro, A. C., Guimarães, P. T. G., \& Alvarez, V. V. H. (1999). Recomendações para uso de corretivos e fertilizantes em Minas Gerais. Viçosa: Comissão de Fertilidade do Solo do Estado de Minas Gerais.

Roosta, H. R. (2011). Interaction between water alkalinity and nutrient solution $\mathrm{pH}$ on the vegetative growth, chlorophyll fluorescence and leaf magnesium, iron, manganese, and zinc concentrations in lettuce. Journal of Plant Nutrition, 34(5), 717-731. https://doi.org/10.1080/01904167.2011.540687

Santos, C. A. B., Rocha, M. V. C., Espindola, J. A. A., Guerra, J. G. M., Almeida, D. L., \& Ribeiro, R. L. D. (2013a). Cultivo agroecológico de berinjeleira sob doses de adubação orgânica em coberturas vivas perenes. Horticultura Brasileira, 31(2), 311-316. https://doi.org/10.1590/S0102-05362013000200022

Santos, H. G., Almeida, J. A., Oliveira, J. B., Lumbreras, J. F., Anjos, L. H. C., Coelho, M. R., Jacomine, P. K. T., Cunha, T. J. F., \& Oliveira, V. A. (2013b). Sistema brasileiro de classificação de solos (3rd ed.). Rio de Janeiro: Embrapa.

Sao, N. V., Mui, N. T., \& Binh, D. V. (2010). Biomass production of Tithonia diversifolia (Wild Sunflower), soil improvement on sloping land and use as high protein foliage for feeding goats. Livestock Research for Rural Development, 22(8), 151.

Shahabi, A., Malakouti, M. J., \& Fallahi, E. (2005). Effects of Bicarbonate Content of Irrigation Water on Nutritional Disorders of Some Apple Varieties. Journal of Plant Nutrition, 28(9), 1663-1678. https://doi.org/10.1080/01904160500203630 
Silva, F. C. (2009). Manual de análises químicas de solos, plantas e fertilizantes. Brasilia: Embrapa.

Széles, A. V., Megyes, A., \& Nagy, J. (2012). Irrigation and nitrogen effects on the leaf chlorophyll content and grain yield of maize in different crop years. Agricultural Water Management, 107, 133-144. https://doi.org/ 10.1016/j.agwat.2012.02.001

Taiz, L., \& Zeiger, E. (2013). Fisiologia Vegetal (5th ed.). Porto Alegre: Artmed.

Ul-Allah, S., Khan, A. A., Fricke, T., Buerkert, A., \& Wachendorf, M. (2015). Effect of Fertiliser and Irrigation on Forage Yield and Irrigation Water Use Efficiency in Semi-Arid Regions of Pakistan. Experimental Agriculture, 51(4), 485-500. https://doi.org/10.1017/S001447971400043X

White, P. J. (2012). Ion Uptake Mechanisms of Individual Cells and Roots: Short-distance Transport. In P. Marschner (Ed.), Marschner's Mineral Nutrition of Higher Plants (pp. 7-47). London: Academic Press. https://doi.org/10.1016/B978-0-12-384905-2.00002-9

Xiao, Y., Zhang, J., Jia, T. T., Pang, X. P., \& Guo, Z. G. (2015). Effects of alternate furrow irrigation on the biomass and quality of alfalfa (Medicago sativa). Agricultural Water Management, 161, 147-154. https://doi.org/10.1016/j.agwat.2015.07.018

Yang, X., Romheld, V., \& Marschner, H. (1993). Effect of bicarbonate and root zone temperature on uptake of $\mathrm{Zn}, \mathrm{Fe}, \mathrm{Mn}$ and $\mathrm{Cu}$ by different rice cultivars (Oryza sativa L.) grown in calcareous soil. Plant and Soil, 155/156, 441-444. https://doi.org/10.1007/BF00025078

Zhang, Y., Yao, Q., Li, J., Hu, Y., \& Chen, J. (2014). Growth response and nutrient uptake of Eriobotrya japonica plants inoculated with three isolates of arbuscular mycorrhizal fungi under water stress condition. Journal of Plant Nutrition, 37(5), 690-703. https://doi.org/10.1080/01904167.2013.868478

\section{Copyrights}

Copyright for this article is retained by the author(s), with first publication rights granted to the journal.

This is an open-access article distributed under the terms and conditions of the Creative Commons Attribution license (http://creativecommons.org/licenses/by/4.0/). 